\title{
5. Hunting the Wild Reciter: Elocution and the Art of Recitation
}

\section{Peter Kirkpatrick}

Despite the endurance of bush poetry festivals and an inner-city fashion for contemporary spoken word and performance poetry, these days the recitation of verse in Australia - as in other Western anglophone nations-remains a minority taste. Early last century, things were very different. In the 1920s, Australians were reciting verse all over the place; so much so that the well-known Bulletin humorist 'Kodak' O'Ferrall lampooned them:

Way out in the suburbs howls the wild Reciter,

Storming like a general, bragging like a blighter;

He would shame hyenas slinking in their dens

As he roars at peaceful folk whose joy is keeping hens.

'How We Beat the Favourite', 'Lasca', 'Gunga Din',

There they sit and tremble as he rubs it in.

When he's done they thank him! Never do they rise,

Tie his hands and gag him as he rolls his eyes,

Bag his head and bear him swiftly through the night.

That's the only remedy for villains who recite. ${ }^{\text {l }}$

Here, from the modern, metropolitan perspective of the professional writer, the reciter is an outlandish form of Homo suburbiensis. An amateur with half-baked literary taste, his choice of party pieces is quaintly Victorian, comprising narrative ballads from Adam Lindsay Gordon to Rudyard Kipling, and extending to Lasca by the Englishman Frank Desprez, in which a Texan cowboy laments the death of his Mexican sweetheart in a cattle stampede. And yet, despite his vulgarity, the reciter's manic energy makes him a force to be reckoned with. It seems only physical violence can put an end to his kind.

This chapter traces the rise and fall of the wild reciter in Australia. In doing so, it takes recitation to refer to the memorisation and public performance of printed verse not written by the reciter, whose repertoire sometimes incorporated the work of canonical poets, but which tended to focus on more popular authors (including stage entertainers), who are now largely forgotten. Reciters might also have included a range of prose highlights and dramatic character sketches in their recitals, but it's evident that rhyming verse in a variety of traditional metres was favoured, and this will be the focus here.

Analysing the historical sources of recitation offers not merely a wistful glimpse into one of the lost arts of everyday life in Australia. It also sheds light on some 
of the ways in which poetry was mobilised by modern popular culture and the new technologies that served it. What follows revisits the broader cultural context in which recitation flourished, outlining three factors that led to its enormous popularity: the growth and spread of elocution, the institutionalisation of recitation in schools, and its professionalisation as a performance art. As the last two are substantially a consequence of the first, elocution will be thematic throughout this account. Indeed, the fate of recitation was tied inextricably to that of elocution - as we shall see by way of conclusion.

Elocution began in the eighteenth century as a means of training lawyers and churchmen in oratory, but by the end of the nineteenth century, it had broadened into a middle-class movement concerned to foster proper and 'natural' - that is to say, middle-class - speech habits. In the words of Dwight Conquergood,

Elocution was designed to recuperate the vitality of the spoken word from rural and rough working-class contexts by regulating and refining its 'performative excess' through principles, science, systematic study, standards of taste and criticism...Ambivalently related to orality, elocution sought to tap the power of popular speech but curb its unruly embodiments and refine its coarse and uncouth features. ${ }^{2}$

In a world without electronic means of amplification, elocution also taught voice projection for all forms of public speaking, professional and amateur, including that for the theatre. The great influence of elocutionary practices throughout the nineteenth century on public entertainments such as lectures, recitals and music hall, in conjunction with an ever-expanding market for ballads and topical verse in newspapers, made the speaking of poetry very popular indeed.

\section{The poetry generation}

In her splendid study of The Victorian Popular Ballad, J. S. Bratton describes the way in which Romantic experiments with the literary ballad interacted with older traditions such as the broadside to produce a new kind of popular verse. An early favourite was Lord Macaulay's Lays of Ancient Rome (1842), which set a fashion for historical ballads across the Empire that lasted well into the twentieth century, and which became institutionalised through recitation in imperial education systems. Macaulay's Lays were set for first-year study in the New South Wales secondary syllabus between 1911 and $1944^{3}$ and clearly had a long afterlife. In the late 1960s, I can recall coming across an extract from Horatius in an early high-school anthology called Poems of Spirit and Action 4 - an old-fashioned collection that also included naval ballads by Henry Newbolt, cowboy poems by Bret Harte and William Rose Benét, as well as The Sick Stockrider by Adam Lindsay Gordon and In The Droving Days by Banjo Paterson. The success of the bush ballad in the Australian context needs to be scrutinised in the light of this wider, imperial taste for literary balladry. Because of its status 
in white Australian folklore, radical nationalists such as Russel Ward saw the bush ballad as a uniquely demotic form, a function of the vernacular realism sponsored by the Bulletin. Yet Richard White has shown how the Bulletin's image of the heroic frontiersman à la The Man from Snowy River was in fact a common literary trope across the British Empire and the United States in the late nineteenth century (Lasca is a perfect case in point). He compares the topos of the city versus the bush in Henry Lawson's work, for instance, with the celebration of colony over metropolis in Kipling: 'It must also be remembered that the bush-worker was an integral part of empire and, when he was ennobled as "the Bushman" and his capacity for drunkenness and blasphemy forgotten, contributed much to imperial ideology.' ${ }^{5}$ Read within this frame, many bush ballads appear less a folkloric expression of Australian national consciousness than local variations of a hegemonic literature of colonial adventure.

The genre of the heroic ballad was so widely popular that, across all class levels, schools encouraged patriotic sentiment through the declamation of prominent examples. ${ }^{6}$ As Terry Eagleton has pointed out, it's hardly coincidental that Henry Newbolt, bard of such Boys' Own classics as Drake's Drum and Vitai Lampada, should also have written the highly influential 1921 British government report The Teaching of English in England. ${ }^{7}$ Bratton notes:

It was this appropriation to schoolroom use... which converted the heroic historical ballad into the staple popular poetry of the middle classes, and imposed upon it the peculiarity of becoming as much oral as written poetry. Children were set to learn these instructive and inspiring pieces; and what is learned must be recited. ${ }^{8}$

Similarly, in the American context, Joan Shelley Rubin has described patriotism as one of three 'prevailing purposes' in school recitation, the other two being 'the cultivation of moral sense and the desire to equip the young with memorised works that could provide "comfort, guidance, and sympathy" throughout life'. 9

Elocutionary belief in the virtue of 'good' speech underpinned recitation in schools. As a popular form of speech training or 'correction', it was important in reshaping individuals, facilitating class mobility by disguising working or lower-middle class or provincial accents - including, of course, Australian accents. The extension of elocution's social function was related directly to the expansion of public education, and consequent concerns about the cultural impact of mass literacy that went hand-in-hand with the rise of English as a subject for schools and an academic discipline. The recitation of verse was seen as a useful skill for 'raising' and standardising pronunciation and thus, supposedly, helping to overcome social division. ${ }^{10}$

In their 1992 oral history of Australian reading practices, Martyn Lyons and Lucy Taksa describe the generation that grew up before and during World War I 
as 'The Poetry Generation', and their interviewees (61 of them, all aged over seventy, born between 1886 and 1917) reported encountering the work of the following poets: ${ }^{11}$

\begin{tabular}{l|l} 
Writers & Mentions \\
\hline Henry Lawson & 32 \\
William Shakespeare & 31 \\
Banjo Paterson & 29 \\
Henry Longfellow & 21 \\
C. J. Dennis & 20 \\
William Wordsworth & 18 \\
Alfred Lord Tennyson & 15 \\
Adam Lindsay Gordon & 14 \\
Rudyard Kipling & 10 \\
Mary Gilmore & 10 \\
John Milton & 10
\end{tabular}

Though Lyons and Taksa are interested in reading rather than recitation, their figures make no clear distinction between these different modes of consumption. As they point out: 'The poetry in the imaginary library of the Australian reader, which we have tried to reassemble here, did not sit silently on the page. It was memorised and recited. ${ }^{12}$ The range of poets recalled by their interviewees represents a span from the low and local (Lawson, Paterson, Dennis), through a middle rank of popular Victorians (Longfellow, Tennyson), to the high and canonical (Shakespeare, Wordsworth, Milton), emphasising the extent to which poetic taste was informed by a school education system that fashioned Australian identity in terms of imperial citizenship. In this list, only three Australian poets and Kipling - and then largely on the basis of their longevity - might be considered twentieth-century writers, and none are modernists.

Rubin's account of recitation in American schools between the wars similarly notes a preference for nineteenth-century material: 'The prescribed texts in 1935 were frequently the same ones tested on college entrance examinations in 1890.'13 She makes the important point that such old-fashioned and occasionally eclectic selections serve to distinguish histories of reading from more conventional literary histories, which privilege innovation: 'Thus the recitation provides a graphic illustration of the discrepancy between textual production and consumption at any given time.' ${ }^{14}$

Pieces selected for reciter books and elocution manuals also offer evidence of this conservative, by now almost customary, form of textual circulation. The eponymous hero of V. S. Naipaul's Trinidadian novel, A House for Mr Biswas, misappropriates a copy of the much-reprinted Bell's Standard Elocutionist as a schoolboy, and the book stays with him throughout his life, as 'his favourite reading ${ }^{15}$ and as the repository of a cultural capital that, however outmoded and irrelevant to his own context, he can never accrue. Biswas was taken out of school just as he had started to memorise Bingen on the Rhine by Lady Caroline 
Norton - an English poem about a dying French legionnaire in Algiers who pines for his hometown in Germany - and it is up to his educated son Anand (a version of the young Naipaul himself) to achieve what was denied his father:

He increased the pathos in his voice, spoke more slowly and exaggerated his gestures. With both hands on his left breast he acted out the last words of the dying legionnaire.

'Tell her the last night of my life, for ere this moon be risen, My body will be out of pain, my soul be out of prison.' 16

Anand's touching performance takes place in the 1940s, when the cultural cringe it represents was still common across the British Empire.

Hugh Anderson's account of reciter books published in Australia between the 1860s and the 1940s reveals that most comprised British and American pieces with a few Australian poems thrown in for local colour. ${ }^{17}$ Among the more enthusiastic anthologists was W. T. Pyke, manager of Cole's Book Arcade in Melbourne, who edited three collections: The Applause Reciter (1898), first published in London, which had no Australian content; The Coo-ee Reciter (1904), with two-thirds Australian material; and The Australian Favourite Reciter (1907), with one-third Australian material. The last was republished as late as 1947, 14 years after Pyke's death, with its 1907 preface and spectral invitation for more contributions intact, and still prophesying 'two or three more books on similar lines'. 18

The great exception to this transnational pattern of choice is The Bulletin Reciter, selected by A. G. Stephens and first published in 1901, which garnered only Australian verse that had appeared in that journal in the previous two decades. It was the most popular of the locally produced reciters and went through at least 14 editions, ${ }^{19}$ the final edition appearing in 1940 and boasting on its cover 'Over 250,000 copies sold'. The original Reciter was replaced in 1920 by a new, updated collection edited by Bertram Stevens, called The Bulletin Book of Humorous Verses and Recitations, which went through at least three editions. In 1933, however, the old Reciter was reinstituted with 'enlarged' contents, ${ }^{20}$ its return highlighting not only the conservatism of popular taste but that recitation was already moribund.

Clearly the success of the reciter books is explained only partly by the promotion of recitation in schools. As already noted, outside the classroom, recitation was also practised widely as a form of entertainment - not only by amateurs, but by professionals from a range of cultural milieux, from local variety performers to world-renowned Shakespearean actors. Their performances are the most visible factor in the popularity of spoken verse, yet, as much as the schoolchild stammering through his or her set piece, they also took place in a world highly attuned to accent and the auditory discipline of elocution. 


\section{Resuscitating an immoral piece of poultry}

Poetry was genuinely popular during the Victorian era in a way that it has never been, before or since. As Bratton observes, social and technological innovations 'from the growth of the industrial towns to the diversification of the periodical press' changed the audiences for poetry and their literary taste. ${ }^{21}$ Les Murray has thus praised the verve and variety of nineteenth-century newspaper poems in Australia, and the way in which popular journals in those days worked to cross-fertilise the high end of verbal art with the low. The Victorian period represented 'the narrow-columned middle ground' of poetry, before the 'social-divide model of Australian verse' ${ }^{22}$ had started to appear, after which literary - and, by implication, modernist - elites overruled the mass of poetry lovers.

It must be remembered that the taste for recitation arose alongside that for public reading, itself the product of an elocutionary culture that sought to regulate the voice as a sign of gentility. Philip Collins has traced the fashion for reading aloud in Britain to the establishment of Mechanics' Institutes, where, from the 1840s, 'readings and other forms of respectable light entertainment came to supplement (later rather to displace)' educational lectures. ${ }^{23}$ According to Collins, 'The common readers' enjoyment of some of the best authors of the age - most notably, of Tennyson and Dickens - must have been reinforced and extended by their hearing of so many of their pieces in recitals, public and private.' As a result, 'many people met contemporary literature as a group or communal, rather than an individual experience'. 24

The relationship between poetry and song during this period is also important. As Murray observed: '[A]s in previous ages, the sharp distinction we make between poetry and song would have seemed strange.' ${ }^{25}$ The Victorian stage was overwhelmingly musical in character, from opera and operetta down to melodrama, fairy ballets and pantomime, but its supreme popular expression was the music hall, in which 'all branches of popular entertainment came to be absorbed'. ${ }^{26}$ With its comic monologues and sentimental ballads, music hall was a powerful influence on the popularity of recitation, and artists such as Bransby Williams, renowned for his rendition of J. Milton Hayes' The Green Eye of the Little Yellow God, became famous. In this context, a clear distinction between recitation and character sketches and songs is often difficult, especially as songs performed by actors were sometimes delivered in a kind of Sprechgesang. In Australia, music halls, as such, had a relatively short history, and were overtaken in the late 1860 s by variety theatres, which appealed to a broader range of classes, and which in turn laid the foundation for the later Tivoli vaudeville circuit, though the style remained derivative of English music hall. ${ }^{27}$

Accordingly, the twentieth-century vaudeville comic Mo (Roy Rene) had a routine in which he attempted to recite The Green Eye of the Little Yellow God, 
only to be interrupted constantly by stooges planted in the audience. Driven to distraction, Mo would splutter, 'Oh this is lovely! This is beautiful! A gentleman and a scholar can't get up to resuscitate an immoral piece of poultry without being got at!' ${ }^{28}$ But even Mo could take himself quite seriously as a reciter. On stage and later on radio, he would occasionally come out with Life is a Very Funny Proposition After All, a mangled version of a piece of homespun wisdom by the American popular entertainer George M. Cohan. As Alexander Macdonald recalled:

$\mathrm{He}^{\prime} \mathrm{d}$ long forgotten most of the words of this piteous lament, but that was no obstacle. He filled in with a few of his own. And the finished product emerged as quite a remarkable length of double-talk:

Life is a very funny proposition after all,

Imagination, hypocrisy and gall,

With not much to say, and two meals a day,

And when you're broke you're always in the way.

And waiting and waiting, and still no curtain call...

Life is a very funny proposition after all.

After putting this across he'd come back stage flushed with triumph. 'I had the mugs weeping,' he'd say, 'Bloody well weeping.'

'They were weeping, all right,' Macdonald added, 'weeping with laughter.' ${ }^{29}$ Yet Fred Parsons, Macdonald's co-writer on the Colgate-Palmolive Radio Unit, who tells much the same story, stated that the audience 'would hang on every word' and give the comic 'a terrific hand'. 30

These stories of Mo's recitations recall the 1940s, when he was a national celebrity, and they mark not only the twilight of public recitation as a performance art but two distinct attitudes to it. On the one hand, the postures and poetic discourse of the reciter provide easy objects of satire. On the other hand, publicly performed verse-however trite - was still able to move an audience. Mo could, with some justification, believe that his rendering of Life is a Very Funny Proposition After All left the mugs in tears.

Outside of music hall and vaudeville, recitation was a predominantly genteel activity, a perceived social accomplishment in the Victorians' endless quest for self-improvement. Middle-class audiences who wouldn't dream of joining the throng 'Down at the Old Bull and Bush' could hear sensational, pathetic or comic verses performed in the parlour or concert hall. As Bratton observes, '[P]erformers like Bransby Williams...were acceptable not for their personal gifts or background but because their material was common to all.' She describes a style of presentation that 'could be transposed from music hall to concert room, even to church hall or private house': 
The ingredients were a strong voice, and a magic lantern: the performer stood in strong spot-light or in dramatic silhouette, and a series of slides depicting scenes in the ballad were thrown on the wall or screen behind, while the artist delivered the ballad with all the dramatic gesturing and vocal acrobatics at his or her command. ${ }^{31}$

As a means of showcasing elocutionary skill, recitation was also part of a professional stage actor's training. ${ }^{32}$ Kenneth Pickering writes: 'It is easy for us to overlook the importance of voice to the nineteenth-century actor and audience... [but] elocutionary display was an accepted and integral part of theatre'; indeed, '[t]o some extent "elocution" became synonymous with acting'. ${ }^{33}$ This involved acquiring a knowledge of prosody, as well as a facility for the semi-dramatic recital of poetry. (It should be recalled, too, that verse plays were commonly produced in the Victorian era; not just those of Shakespeare and his contemporaries, but what we would now regard as the closet dramas of poets from Byron to Tennyson.) Some of the great Victorian actors became identified with their rendition of particular poems - for example, Henry Irving with Thomas Hood's eerie confessional The Dream of Eugene Aram - and the widespread popularity of recitation produced a new kind of professional platform recitalist who would often use music to enhance the emotional effect. ${ }^{34}$ In Australia, one such was Lawrence Campbell, who was seen as pre-eminent in his field, ${ }^{35}$ and a typical recital was described in the Theatre Magazine in 1905:

The principal interest in an entirely new programme will centre [on] $\mathrm{Mr}$ Campbell's delivery of Tennyson's well-known poem, 'The Lady of Shalott', with a piano, violin and 'cello accompaniment.

Other elocutionary items will include a selection from Macbeth, Act IV, Scene I, characters represented-Malcolm, Macduff, and Rosse [sic]. 'The Village Priest', by Farcalladen Moor, with musical accompaniment by Miss Lilian Frost; and two humorous sketches, 'The Family Vault', by Max Adler, and the 'Two Scars', by Overton. ${ }^{36}$

Though a distinction was drawn between platform and stage performance, the perceived benefits of elocutionary training allowed considerable overlap. Theatre Magazine described veteran actor William Holman as 'one of the most popular reciters and successful teachers of elocution in Sydney', who had coached state and federal MPs - including his own son, the future Labor Premier W. A. Holman - in voice production. ${ }^{37}$ Advertisements in the journal for drama teachers constantly link platform and stage. Holman offered lessons in 'elocution, voice culture, dramatic art', and Campbell described himself as a 'teacher of elocution and dramatic art' ${ }^{38}$ Actor-manager Duncan Macdougall, who set up Sydney's pioneering Playbox Theatre in the 1920s, began his career as a teacher 
of elocution and trained future Presbyterian ministers in public speaking at St Andrew's College at Sydney University. ${ }^{39}$

The solid popularity of recitation in the early 1900s makes its sudden decline by mid-century the more remarkable. After all, it had behind it the institutional support of the education system and many prominent people in public life, including some in what we would now call the entertainment industries. Encouraged by a network of teachers of elocution, and fed by an ever-expanding range of recitation books, the wild suburban reciter was in his glory. To find out why public taste turned so decidedly against him - why Kodak wanted to 'Bag his head and bear him swiftly through the night' - we need to consider some effects of the new audial landscape that arrived with the turn of a dial shortly after World War I.

\section{Radio killed the poetry star?}

What killed recitation as a popular art? In The Oxford Companion to Australian Folklore, Keith McKenry blames the new media technologies 'combined with normal social change' for the decline of recitation from the 1920s. ${ }^{40}$ If this is true, it is not simply true, as radio arguably brought new opportunities for extending poetry as entertainment across the airwaves. The $\mathrm{ABC}^{\prime} \mathrm{s}$ John Thompson, who himself fostered such hopes through programs such as Quality Street, quoted the English poet D. G. Bridson, who in 1950 believed that there was 'every reason to class the invention of the microphone with those of writing and the printing press'. By 1966, however, as Thompson ruefully remarked, 'Bridson's hopes [had] hardly been fulfilled'. ${ }^{1}$ What had happened?

Firstly, as Les Murray observed, poetic culture began to bifurcate under the impact of modernism, with its emphasis on a less public, more intimate voice modulated in free verse. Designed to be sounded mentally rather than spoken out loud, modernist verse was tailored to an audience of individual readers, not gatherings of auditors. Fuelling this shift in attitude was the fact that elocutionary techniques did not transfer well to the electronic media. The informal kind of voice required for radio was precisely the opposite needed for histrionic declamation in large, draughty halls and theatres, and, as listeners became quickly habituated to the paradoxical intimacy of public broadcasting, the former advantages of elocutionary training became liabilities. In this process, the mnemonic and incantatory effects of traditional metres were downgraded, becoming associated with complacent and conservative social attitudes-what George Orwell, in a famous critique of Kipling, called 'good bad poetry'. ${ }^{42}$

Secondly, recitation was strongly associated with the artificiality of elocution, and therefore suffered by association when performance fashions turned against it. Elocution always had a problematic relationship with 'nature'. In their attempt to reform the common vices of static or unanimated oratory, the 
eighteenth-century pioneers of elocution had endeavoured to develop a universal grammar of emotion linked to bodily gesture: '[N]ature has given to every emotion of the mind its proper outward expression,' wrote James Burgh, author of The Art of Speaking (1762). ${ }^{43}$ Not surprisingly, as the elocutionary movement burgeoned during the nineteenth century in a host of manuals illustrating recommended poses and hand movements, this simple idea became rigidly codified. As Frederick William Haberman has written: 'The inevitable result of this conception of natural determinism in emotional expression is the degeneration of the philosophy of delivery into a study of symbolical expression, or formalized action, of regulated postures, of designated maneuvers [sic]. ${ }^{44}$ In a version of Bell's Standard Elocutionist republished as late as 1938, the reader is told 'that gesture must appear spontaneous, must seem to rise, as a result of unstudied impulse, from the words which are being spoken'. ${ }^{45}$ Yet two pages later, under the heading 'Full Gesture', we are told:

Every accentual action should be preceded by a prepatory movement in the opposite direction to where the movement will end, the gesture needing somewhere to move from.

As a general principle, either the upper side (the thumb), or the back of the hand, should be turned in the direction of the gesture in upward motions; and the lower side, or the palm of the hand, in downward motions.

The feet should preserve a uniform angle of separation in every motion, the toes being turned outwards to an angle of not more than 75 degrees. ${ }^{46}$

So much for spontaneity! Haberman argues that, as a product of Enlightenment scientism, elocution was always mechanistic in its approach, even though its originators saw themselves as merely following natural precepts: 'Implicit in the minds of the elocutionists was the sense of a mechanical order in nature. Thus they could claim that their rules and their systems represented the order that is found in nature; they were "nature still, but nature methodized". 47

Even before radio, in the theatre, the advent of naturalism in the late nineteenth century started to give the histrionics of elocutionary training a bad name - a situation, as Kenneth Pickering notes, 'greatly complicated by the large numbers of amateur performers trying to teach themselves the socially desirable skill of recitation' ${ }^{48}$ Writing on 'The elocutionist and the actor' in Theatre Magazine in 1913, Lawrence Campbell commented:

If one thing more than another has helped to bring the elocutionary profession into disrepute it is the failure on the part of the majority of interpreters, both professional and amateur, to realise the limitations of their art - a failure which has lead [sic] to an excessive and exaggerated 
form of action and impersonation as artificial and unconvincing as it is strenuous and inartistic. ${ }^{49}$

To take just one example, for 20 years until his death in 1950, an eccentric known only as The Tiger, or the Tangalooma Tiger, and describing himself as 'a full-blooded elocutionist', drew substantial crowds to his recitations of Henry Lawson and Shelley at the Sydney Domain. ${ }^{50}$

Recitation and elocution were at last parting company, and if elocution itself was changing it was a little too late to save its name. Mark Morrisson describes the emergence of a 'new elocution' in Britain at the turn of the twentieth century that valued restraint and a lack of theatrical effects, emphasising the reciter's role in bringing forth the latent 'pure voice' of the poem itself. He quotes Lady Margaret Sackville, whose inaugural address to the Poetry Society in 1912 advised that ' $[\mathrm{t}]$ here should be no striving from outside to produce a definite effect - the soul of the interpreter should be so possessed by the poem that it follows it instinctively in every modulation and inflection as easily as water flowing between winding banks' ${ }^{51}$ Though the new elocutionists were literary conservatives, Morrisson argues that their stress on unadorned performance - the purely oral over the visual and dramatic — was a powerful influence on early modernist poetry's desire to break free of Victorian mannerisms and, in T. S. Eliot's words, 'purify the dialect of the tribe'.

In the Australian context, these ideas are implicit in the comments of one elocutionist, who told readers of the Age in 1938: "The word "elocution" is associated in the minds of most people with recitations, or as some artificial manner of speech. This is easily understood, because in schools and academies reciting is the only medium through which elocution is taught. ${ }^{52}$

True elocution, the writer believed, was simply the art of speaking clearly so as to fully articulate the sound of the words. The year before, in Australian Musical News, an 'Examiner in Elocution' similarly insisted: 'Audibility, good vocal tone, rhythmic flow, naturalness, and sincerity, coupled with understanding and feeling, are, in short, the essentials of good verse speaking, and the lack of these qualities can never be compensated for by artificial expression or the theatrical methods dear to the elocutionists of the past. ${ }^{253}$

In her history of early Australian radio, Lesley Johnson has described the evolving style of presentation from the 1920s, when 'advertisements for new programmes occasionally mentioned that the announcer was a "fine elocutionist"', to the 1930s, when radio 'personalities', noted for their intimate, friendly manner, started to come into their own. ${ }^{54}$ In the 1950s, when the career of radio superstar and sometime poet John Laws was just beginning, one Western Victorian reciter gave up performing because he felt that he and his fellows were now regarded as 'bits of fools' ${ }^{55}$ Radio thus helped kill the wild reciter, not simply by offering 
alternative entertainment, but by finally dispensing with the last vestiges of an elocutionary ethos that had sustained the art of recitation for more than a century. Elocution flourished on the stage and in the public readings and recitals of early industrial society, but the new audiences so formed would become the basis of a modern mass culture that has so far proved mostly unfriendly to poetry.

\section{ENDNOTES}

${ }^{1}$ Kodak (Ernest O'Ferrall) 1928, Odd Jobs, Art in Australia, Sydney, n.p.

2 Conquergood, Dwight 2000, 'Rethinking elocution: the trope of the talking book and other figures of speech', Text and Performance Quarterly, Vol. 20, No. 4, pp. 326-7.

3 Watson, Ken 1996, 'English Teaching in Historical Perspective: Case Study of an Australian State', in Ken Watson (ed.), English Teaching in Perspective in the Context of the 1990s, Third Edition, St Clair, Sydney, pp. 28-9.

4 See Smyth, W. M. (ed.) 1957, Poems of Spirit and Action, Edward Arnold, London, pp. 126-33.

5 White, Richard 1981, Inventing Australia: Images and Identity 1688-1980, George Allen and Unwin, Sydney, p. 103.

6 See Bratton, J. S. 1975, 'The Heroic Ballads', The Victorian Popular Ballad, Macmillan, London and Basingstoke.

7 Eagleton, Terry 1983, Literary Theory: An Introduction, Basil Blackwell, Oxford, p. 28.

8 Bratton, The Victorian Popular Ballad, p. 49.

9 Rubin, Joan Shelley 1997, “"They flash upon that inward eye": poetry recitation and American readers', Proceedings of the American Antiquarian Society, American Antiquarian Society, Worcester, Mass., p. 275.

10 See Muddlestone, Lynda 1995, 'Educating Accents', 'Talking Proper': The Rise of Accent as Social Symbol, Oxford University Press, Oxford, especially pp. 308-9.

11 Lyons, Martyn and Taksa, Lucy 1992, Australian Readers Remember: An Oral History of Reading 1890-1930, Oxford University Press, Melbourne, pp. 59-60.

12 Ibid., p. 68.

13 Rubin, “"They flash upon that inward eye"”, p. 274.

14 Ibid., p. 275. Also see Rubin, Joan Shelley 1998, 'Listen, My Children: Modes and Functions of Poetry Reading in American Schools, 1880-1950', in Karen Halttunen and Lewis Perry (eds), Moral Problems in American Life: New Perspectives on Cultural History, Cornell University Press, Ithaca, NY, p. 261.

15 Naipaul, V. S. 1969, A House for Mr Biswas, Penguin, Harmondsworth, p. 161.

16 Ibid., p. 415. Recitation of this poem also features, more romantically, in the Canadian novel Anne of Green Gables.

17 Anderson, Hugh 2001, 'That face on the bar-room floor, or, Where have all the reciters gone?', Australian Folklore, No. 16, pp. 190-3.

18 Pyke, W. T. 1947, 'Preface', The Australian Favourite Reciter, J. Pollard, Melbourne, n.p.

19 Anderson, 'That face on the bar-room floor', p. 191.

20 [Stephens, A. G. (ed.)] 1933, The Bulletin Reciter: Collection of Verses for Recitation: From the Bulletin: Enlarged Edition, NSW Bookstall Co., Sydney. The contents were expanded by the addition of a mere four poems by W. T. Goodge. By this time, The Bulletin Book of Humorous Verses and Recitations was now advertised as The Bulletin Reciter No. 2, endpapers.

21 Bratton, The Victorian Popular Ballad, p. 12.

22 Murray, Les 1992, 'The Narrow-Columned Middle Ground', The Paperbark Tree: Selected Prose, Carcanet, Manchester, p. 240.

23 Collins, Philip 1972, Reading Aloud: A Victorian Métier, The Tennyson Society, Lincoln, p. 11.

24 Ibid., p. 27.

25 Murray, 'The Narrow-Columned Middle Ground', p. 233.

26 Bratton, The Victorian Popular Ballad, p. 27. 
27 Waterhouse, Richard 1995, 'Music Halls', in Philip Parsons (ed.), Companion to Theatre in Australia, Currency with Cambridge University Press, Sydney, p. 381.

28 Macdonald, Alexander 1972, The Ukelele Player Under the Red Lamp, Angus and Robertson, Cremorne, p. 224.

29 Ibid., pp. 229-30.

30 Parsons, Fred 1973, A Man Called Mo, Heinemann, Melbourne, p. 83.

31 Bratton, The Victorian Popular Ballad, p. 107.

32 Pickering, Kenneth 1984, 'The rise of elocution-continued', Speech and Drama, Vol. 33, No. 1, p. 4.

33 Pickering, Kenneth 1983, 'The rise of elocution', Speech and Drama, Vol. 32, No. 2, p. 9.

34 Pickering, 'The rise of elocution-continued', pp. 7-8.

35 He featured on the cover of Theatre Magazine, 1 July 1919, as 'Australia's most distinguished platform entertainer'.

36 'Mr Lawrence Campbell', Theatre Magazine, 1 April 1905, p. 10.

37 'Mr William Holman', Theatre Magazine, 1 April 1905, p. 8.

38 Theatre Magazine, 1 November 1911, p. 14.

39 Kirkpatrick, Peter 2000, 'Macdougall, Augusta ("Pakie") and Duncan', in John Ritchie (ed.), Australian Dictionary of Biography, Vol. 15, Melbourne University Press, Carlton South, p. 199.

40 McKenry, Keith 1993, 'Folk Poetry and Recitation', in Gwenda Bede Davey and Graham Seal (eds), The Oxford Companion to Australian Folklore, Oxford University Press, Melbourne, p. 152.

41 Thompson, John 1966, 'Broadcasting and Australian Literature', in Clement Semmler and Derek Whitelock (eds), Literary Australia, F. W. Cheshire, Melbourne, p. 97.

42 Orwell, George 1970, 'Rudyard Kipling', in Sonia Orwell and Ian Angus (eds), The Collected Essays, Journalism and Letters of George Orwell: Volume II: My Country Right or Left 1940-1943, Penguin, Harmondsworth, pp. 226-8.

43 Cited in Haberman, Frederick William 1947, The elocutionary movement in England, 1750-1850, $\mathrm{PhD}$, Cornell University, p. 113.

44 Ibid., p. 129.

45 [Bell, Alexander Melville] 1938, The Standard Elocutionist: A Complete Book on the Science and Art of Easy, Clear, Effective and Expressive Speech, Compiled, with Revisions and Additions, from Bell's Standard Elocutionist, English Universities Press, London, p. 43.

46 Ibid., p. 45.

47 Haberman, The elocutionary movement in England, 1750-1850, p. 50.

48 Pickering, 'The rise of elocution-continued', p. 5.

49 Campbell, Lawrence 1913, 'The elocutionist and the actor', Theatre Magazine, 1 November 1913, p. 6.

50 Maxwell, Stephen 1994, The History of Soapbox Oratory: Part One: Prominent Speakers of the Sydney Domain, self-published, Chiswick, p. 23.

51 Cited in Morrisson, Mark 1996, 'Performing the pure voice: elocution, verse recitation, and modernist poetry in prewar London', Modernism/Modernity, Vol. 3, No. 3, p. 32.

52 Besant, R. E. 1938, 'What is elocution?', Age Literary Supplement, 29 October 1938, p. 3.

53 Edmonds, Paul 1937, 'The art of speaking verse', Australian Musical News, 1 January 1937, p. 8.

54 Johnson, Lesley 1988, The Unseen Voice: A Cultural Study of Early Australian Radio, Routledge, London, p. 47; also see p. 71.

55 Peter Hay, cited in McKenry, 'Folk Poetry and Recitation', p. 151. 